\title{
Wage Formation under \\ Union Threat Effects: \\ Theory and Empirical Evidence
}

Giacomo Corneo and Claudio Lucifora ${ }^{*}$

September 1993

$\mathrm{N}^{\circ} 9318$

* We would like to thank Robert Boyer, Pierre Cahuc, Andrew Clark, Pascal Petit and participants to CEPREMAP seminar, where a previous version of this paper was presented. This paper was written while both authors were visiting CEPREMAP, whose hospitality is gratefully acknowledged. Usual disclaimer applies. 


\title{
Wage Formation under Union Threat Effects: Theory and Empirical Evidence
}

\author{
Giacomo Corneo \\ CEPREMAP \\ and \\ Claudio Lucifora \\ Università Cattolica di Milano
}

\begin{abstract}
This paper examines wage formation under union threat effects, investigating the possibility that trade union activity may have an impact on wages outside the bargaining sector. A game theoretic formuiation of wage formation under decentralised bargaining is presented, and the strategic elements which characterise union behaviour in wage negotiations modelled. We show that in the unique subgame perfect equilibrium of the model, according to different union density levels, alternative wage determination patterns may emerge. Namely, in firms with low union density no collective bargaining is observed and the wage outcome equals the reservation wage. For intermediate density levels, the union threat is effective and the wage level is higher than the reservation wage even if there is no collective bargaining. Finally, in highly unionised plants collective bargaining is the norm and, consequently, threat effects are ineffective. An empirical specification of the model, suitable for estimation, is then derived and fitted to establishment-level data for the Italian metalmechanical engineering industry. Empirical results suggest the presence of endogenous selectivity in the choice of the bargaining regime, and confirm the existence, according to local union density, of different wage determination patterns. Among these, threat effects are shown to be significant at the intermediate density level.
\end{abstract}

Keywords and JEL classification: Wage bargaining, Union threat - J3I, J51

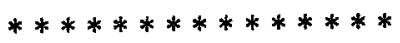

\section{Formation des salaires et effets de menace syndicale: théorie et evidence empirique}

\section{Résumé}

Dans le texte nous étudions la détermination du taux de salaire en présence d'effets de menace syndicale (union threat effects): en menaçant d'entreprendre une action collective, le syndicat peut induire l'entreprise à verser un salaire supérieur à celui de l'équilibre compétitif, même sans négocier. Cette idée est formalisée à l'aide d'un jeu séquentiel entre syndicat et entreprise, dans lequel le taux de syndacalisation affecte le processus aléatoire qui détermine la probabilité d'observer la négociation collective. Dans le seul équilibre parfait du modèle, le mode de formation du salaire rentre dans un des cas suivants: (i) dans les entreprises où le taux de syndacalisation est faible, il n'existe pas de négociation collective et les entreprises versent le salaire de réservation; (ii) lorsque le taux de syndacalisation se trouve dans une région intermédiaire, la menace syndicale est efficace: le salaire est supérieur au niveau de réservation, bien qu'on n'observe pas de négociation; (iii) pour des niveaux élevés de syndacalisation, le résultat prbable est la négociation collective et la menace syndicale n'est pas efficace. Puis, nous dérivons une spécification empirique du modèle, que nous testons en utilisant des données individuelles concernant 3000 établissements de l'industrie métallurgique-mécanique italienne. Les résultats de l'analyse empirique suggèrent la presence d'une sélection endogène du regime de determination du salaire, et confirment l'existence des modes de formation du salaire qui sont exprimés par le modèle théorique. En particulier, les effets de menace syndicale sont significatifs lorsque le taux de syndacalisation de l'établissement est situé dans l'intervalle intermediaire.

Mots clés et Code JEL: Négociation salariale, Menace syndicale - J31, J51 


\title{
Wage Formation under Union Threat Effects:
}

\author{
Theory and Empirical Evidence
}

\section{Introduction}

Trade unions influence wage formation by means of collective bargaining; through market spillovers, they affect the whole price structure and, in particular, nonunion wages. Along with market effects, trade unions may have an impact on wages outside the bargaining units through more direct "strategic" effects. The effect which most of the literature has retained as the principal one is the union threat effect, according to which employers wishing to prevent collective bargaining must come close to matching union wages (Rosen, 1969; Dickens, 1986). Thus, even if formal wage negotiations cover only a small fraction of total wage-bill, the overall effect of unionism on the structure of relative wages may be larger due to the threat of workers' collective action. In this paper we develop a theoretical framework devoted to this contention and then test it using establishment-level data for the Italian metal-mechanical industry.

A seminal contribution to the modelling of the threat hypothesis is due to Dickens (1986). In fact, most of the empirical literature which ties the percent organised in an industry to the wages of nonunion workers, as argued by Neumark and Wachter (1992), can be interpreted as testing the validity of that model. However, as Dickens (1986) himself stresses, his model is tailored to represent the specific situation faced by a modern US firm ${ }^{1}$. By contrast, the model which will follow is meant to capture stylised facts common to various institutional settings faced by European firms. In particular, it can be noted that several European countries are characterised by a two-stage wage formation

1 Dickens (1986) assumes that if a certain fraction of a firm's workforce wishes to bargain collectively, then the firm must do so; he interprets this fraction as the majority that must vote to certify a union under the National Labor Relations Act. Furthermore, in his model the union might sign a contract which offers unionised workers a higher wage than to the rest of the workforce. This is in contrast with evidence in continental Europe, where collectively negotiated wages apply to all workers, irrespectively of their union status. 
mechanism: first, a wage floor is set by minimum wage laws or by national collective bargaining; second, decentralised bargaining may take place at the plant level with local unions negotiating with company management over pay and other issues. In recent years, the diffusion and the relevance of decentralised bargaining for wage formation has gained increasing importance (Blanchflower and Freeman, 1990; Flanagan et al., 1992).

It is on this aspect of the wage determination process and on the strategic elements involved that the present paper wishes to focus. In this light, we provide a gametheoretical formulation of decentralised wage negotiations and of the threat effects involved.

In the theoretical model we assume that in each firm a given fraction of the workforce is unionised. Union members may decide to ask for local wage bargaining, in which case the resulting wage applies to all employed workers, irrespective of their union status. However, the incidence of local bargaining depends on the local union density as well as union's intentions. We use union density at the firm as a proxy of the strength of the union in inducing local wage negotiations. We show that in the unique subgame perfect equilibrium of the model, three wage formation patterns may appear. In firms with low union density we find that there is no collective bargaining (threat effects are non-binding) and the wage equals the reservation wage. For intermediate density levels, the firms can still avoid collective bargaining but the union threat is effective: the wage level is therefore higher than the reservation wage. In strongly unionised firms, collective bargaining occurs with high probability but the union threat does not affect the wage offered by the management (the wage threat is ineffective). In our model, the wage turns out to be an increasing function of both union density and union bargaining power, irrespectively of the occurrence of collective bargaining. This property is extensively used in the second part of the paper in order to test the validity of the threat hypothesis for the Italian labour market.

Whilst many empirical studies on the effects of unionisation on relative wages have documented the positive impact of trade union activity on the wage levels of unionised workers (Lewis, 1986; Stewart, 1983), little attention has been paid, in general, to the effects of trade union activity on the nonunion sector of the economy. The first attempt to 
test the hypothesis that wage increases in the unionised sector could, via threat and other indirect effects, affect nonunion wages is due to Rosen (1969). Using 2-digit industry US Census data he provided evidence in support of wage spillover effects from the unionised sector to the nonunionised sector due to threat responses of nonunion firms resulting in higher nonunion wages. More recent papers by Freeman and Medoff (1981), Dickens and Katz (1987a,b), and Neumark and Wachter (1992) have addressed the same issue, in the context of the US economy, and found mixed results. It should be noted, however, that the use of aggregate industry level data for union presence variables (i.e. either total union membership or collective bargaining coverage), makes the interpretation of the underlying effects difficult as specification and aggregation problems may affect the results (Lewis, 1983; Geroski and Stewart, 1986). Although not much empirical evidence exists on this issue, to our knowledge, for other countries, some work has been done using Italian data. Dell'Aringa and Lucifora (1992), using establishment level data, estimate union-nonunion wage differentials under decentralised bargaining and argue in favour of union threat effects in the sector with no formal local wage agreements in force.

A problem common to all the empirical studies reviewed thus far has to do with the modelling of the negotiation process, since the decision of whether to bargain or not is taken as exogenous and therefore independent of wage determination. However, under union threat effects the probability of observing a local wage agreement is likely to depend on both the costs of bargaining and the expected wage gain from bargaining. In other words, if the division between the two alternative wage determination regimes (i.e. bargaining and no-bargaining) does not follow a pure random process, then estimates might suffer from selectivity bias as local unions will - ceteris paribus - sort themselves into the wage regime which pays them the highest. In the present study, we deal with the endogeneity issue by means of an endogenous switching regression model, and test for the existence of selectivity bias across alternative wage formation regimes (Lee, 1978; Maddala, 1983; Duncan and Leigh, 1985).

The rest of the paper is organised as follows. In section 2 , the theoretical model is presented and its implications for the empirical analysis discussed. Section 3 derives an 
empirical specification suitable for estimation, while section 4 describes the data used. The main set of results is presented and discussed in section 5. Some concluding remarks appear in the last section.

\section{The theoretical framework}

\subsection{Assumptions}

We model wage formation within a firm in a competitive industry as a sequential game played by the firm's management and the local union. The management's payoff function is the firm's profit, which is written as $\pi=(v-w) L$, where $v$ is the value of the constant marginal productivity of labour, $w$ is the wage rate and $L$ is employment ${ }^{2}$. The firm is endowed with a pool of workers, from which the firm can hire. Each pool is constituted by a continuum of workers, uniformly distributed on the unit interval, $I=[0,1]$. Each worker inelastically supplies one unit of labor to the firm. An exogenously given fraction $\mu \in[0,1]$ of the firm's total workforce consists of workers who are union members ${ }^{3}$. The union's payoff function is the expected utility of the union member, which is written as $U=L(w-\delta c)$, where $L$ represents the employment probability (unemployment utility is assumed to be nil, without loss of generality); $\delta$ is a dummy variable which is 1 if the union conducts local wage negotiations and is 0 otherwise; $c$ represents the net costs of bargaining organisation per union member ${ }^{4}$. Whenever there is local wage bargaining, the negotiated wage applies to all employees in the firm, irrespectively of their union status. Furthermore, due to constant returns, the firm optimally

\footnotetext{
2 Adopting a strictly concave revenu function would alter our result concerning the employment level but would leave results about wages and threat effects qualitatively unaltered. Since the latter is the focus of this paper, we adopt the present specification for its greater simplicity.

${ }^{3}$ Union membership is compulsory under closed shop arrangements. From an empirical viewpoint, the case of voluntary union membership - the open shop - is much more relevant. For a theoretical investigation of determinants of the union density in open shops, see Naylor and Cripps (1993) and Corneo (1993).

4 We neglect the firm's bargaining costs for simplicity; the presence of such costs would leave unaltered the logic of the paper.
} 
hires all workers in the pool, i.e. $L=1$, as long as the wage rate is less than the value of the marginal productivity of labour.

The extensive form of the game tries to capture institutional features common to several European labour markets. In the first stage of the game, the management promises to pay a wage rate $w_{n} \geq \underline{w}$ to each worker, where $\underline{w}<v$ is referred to as the reservation wage and represents the (exogenously given) best outside option for the worker. It may also be thought of as a wage minimum statutorily fixed by the government or as a wage set by previous more centralised negotiations. In the second stage, the local union makes a dichotomous decision, represented by the dummy variable $d$. It may decide either "to do nothing" $(d=0)$ or to ask for local wage negotiations with the management $(d=1)$. In the first eventuality, the wage rate stays fixed at $w_{n}$, production occurs and the game ends. In the second eventuality, the organisation drive may either be successful (with probability $\rho$ ) or not (with the complementary probability). In the latter case, the wage rate stays fixed at $w_{n}$, production occurs and the game ends. If the organisation drive is successful, the game enters its third stage. The management and the local union bargain over the wage rate by making alternating offers (Rubinstein, 1982); only in this case, $\delta=1$. Once the wage is set, production occurs and the game ends.

The move structure of the game contains two specific elements, which are common to actual wage setting in unionised labour markets. First, the possibility for the firm to pay a higher wage than the minimum, independently of local wage bargaining. This behaviour can have various motivations, e.g. it can arise in an efficiency wage context. In our model it might be motivated by the union's threat of collective action. Second, the move structure allows for the possibility of firm-level bargaining supplementing previous higher-level negotiations. However, in our model such a possibility does not depend only on the union's intentions; rather, the institutional context determines the probability with which such an eventuality will occur.

We make the following additional assumptions.

(A1): $\rho$ is a non decreasing function of $\mu$; we write $\rho=\rho(\mu)$. 
Thus, whenever the local union tries to induce local wage bargaining, the probability that it succeeds does not decrease with union membership. This assumption captures the fact that the union size often is, formally or substantially, an important factor for union recognition at the firm level.

(A2): $c$ is a continuous, strictly decreasing function of $\mu$; we write $c=c(\mu)$.

We provide two justifications for this assumption. First, local wage bargaining typically involves some fixed costs for the trade union, i.e. independent of its size. Second, bargaining may induce social custom effects, by which net bargaining costs - interpreted as incorporating also non-pecuniary effects of collective bargaining - are lower, the greater is the union density ${ }^{5}$. Moreover, as noted by Dickens (1986), social custom effects might even induce negative bargaining costs.

(A3): $s<\underline{w}<\alpha v+(1-\alpha) s$,

where $\alpha \in(0,1)$ is union bargaining power and $s>0$ is union member income during a dispute. According to the strategic rationalisation of the Nash solution provided by Binmore et al. (1986), the bargaining power should merely capture asymmetries in the bargaining procedure and in discount factors. Union member income during a dispute should equal strike pay ${ }^{6}$, provided that it is financed mainly by union members outside the firm. Otherwise it should consist of income from temporary jobs which union members pick up during the strike (Layard et al., 1990). Assumption (A3) fixes a range of possible

5 The theory of social custom was applied for the first time in a union context by Booth (1985); see also Naylor (1989). In the context of our model, union members would derive an additional "reputation utility" from membership only when the local union bargains with the management. This reputation effect would then be an increasing function of union membership.

6 The dispute might also take other forms, e.g. work-to-rule, go-slow, wild cat strike (Moene, 1988). Adopting one of these possibilities would not alter the logic of the model. 
values for the minimum wage; its main justification is analytical convenience, although an economic interpretation in terms of two-level wage bargaining might also be provided.

\subsection{Results}

We analyse the model by backward induction in order to determine its subgame perfect Nash equilibria (SPNE). When the third stage of the game is reached, the management and the union bargain over the wage rate by making alternating offers. Following Binmore et al. (1986), the outcome of bargaining is given by the generalised Nash solution, provided that it is larger than the wage minimum. The Nash solution is written as:

$w_{c}=\underset{w}{\arg \max }(U-\underline{U})^{\alpha}(\pi-\underline{\pi})^{1-\alpha}$

where $\underline{U}$ and $\underline{\pi}$ are, respectively, the fallbacks of the union and the management. The fallback value represents the bargainer's payoff during a dispute, - i.e. a strike in the present context. We posit that $\underline{U}=s-c$ and $\underline{\pi}=(v-w)(1-\mu)$, which means that only union members adhere to the strike called by the union and that remaining workers are paid their reservation wage. What is crucial for our results is only that the harm inflicted to the firm during the dispute is an increasing function of union membership. Substituting into [1] for the two payoff functions and fallback values, one obtains the following wage rate:

RESULT 1. $\quad w_{c}=\alpha \mu v+\alpha(1-\mu) \underline{w}+(1-\alpha) s$.

The wage given by the Nash solution is a convex combination of the value of labour productivity, the reservation wage, and the strike pay. Hence, we have the following fact. 
LEMMA 1. There exists $\underline{\mu} \in(0,1)$ such that $w_{c}>\underline{w}$ if and only if $\mu>\underline{\mu}$.

Proof. By result $1, w_{C}$ is a continuous, strictly increasing function of $\mu$. If $\mu=0$, then $w_{c}=\alpha \underline{w}+(I-\alpha) s$, which is smaller than $\underline{w}$ by (A3); if $\mu=1$, then $w_{c}=\alpha \nu+(1-\alpha) s$, which is larger than $\underline{w}$ by (A3). Whence, there exists $\underline{\mu} \in(0,1)$ such that $w_{C}=\underline{w}$, and the assertion follows. QED

In the second stage of the game, the local union decides whether to stay passive $(d=0)$ or to seek to obtain the wage negotiation with management $(d=1)$. We denote by $U_{0}$ and $U_{l}$ the expected payoff of the union in the two cases, respectively. A "passive" local union does not bargain over the wage rate; therefore, $U_{0}=w_{n}$. To an "active" union bargaining happens with probability $\rho$, which implies:

$U_{1}=\rho(\mu)\left[\max \left(w_{c}(\mu), \underline{w}\right)-c(\mu)\right]+(1-\rho(\mu)) w_{n}$

In order to characterise the union strategy in equilibrium, it is convenient to make a further assumption about the effect of union density on per capita bargaining costs as compared to its effect on wage bargaining:

(A4): there exists $\mu^{\circ} \in(\underline{\mu}, I)$ such that $c>0$ if and only if $\mu<\mu^{\circ}$.

Thus, we allow for the possibility of negative bargaining costs, as previously mentioned; however, the required union density is assumed to be larger than the minimum union density which is necessary in order to increase the wage rate above the minimum through local bargaining.

Now we are ready to characterise the union's equilibrium strategy. 


\section{RESULT 2.}

(A). Suppose $\mu \leq \mu$; in every SPNE, $d=0$.

(B). Suppose $\mu>\mu$; in every SPNE, $d=I$ if and only if $w_{n}<w_{c}-c \equiv w^{\wedge}$.

Proof. (A). If $\mu \leq \mu, w \geq w_{c}$ by lemma 1 and $c>0$ by (A4); whence, $U_{1} \leq U_{0}$ and $d=0$ is the dominant strategy (we suppose for simplicity that if $U_{1}=U_{0}$, the union's choice is $d=0$ ).

(B). If $\mu>\underline{\mu}, w_{c}>\underline{w}$ by lemma $1, U_{1}=\rho\left(w_{c}-c\right)+(I-\rho) w_{n}$, and $U_{0}=w_{n}$. The union's optimal strategy is $d=I$ if and only if $U_{1}>U_{0}$, which is equivalent to $w_{c}-c-w_{n}>0 . \quad \mathrm{QED}$

When the union density is relatively small, collective bargaining cannot induce any wage increase above the minimum and therefore the union refrains from bargaining. When the density is relatively large, the union might ask for local negotiations. It does so if the net wage increase that the union can obtain offsets the wage increase that is unilaterally offered by the management.

In order to determine the equilibrium path, we have now to turn to the first stage of the game.

\section{RESULT 3.}

(A). Suppose either $\mu \leq \underline{\mu}$ or $\mu>\mu^{\circ}$; in every SPNE, $w_{n}=\underline{w}$.

(B). Suppose $\underline{\mu}<\mu \leq \mu^{\circ}$; in every SPNE:

(i) $w_{n}=\max \left(w^{\wedge}(\mu), w\right)$ if $(l-\rho(\mu))\left(w_{c}(\mu)-w\right) \leq c(\mu)$;

(ii) $w_{n}=\underline{w}$ if $(l-\rho(\mu))\left(w_{c}(\mu)-\underline{w}\right)>c(\mu)$.

Proof. (A). First, suppose $\mu \leq \underline{\mu}$. By result $2 . \mathrm{A}$, in a SPNE, $d=0$, which implies $\pi=v-w_{n}$. Whence, the management's optimal strategy is $w_{n}=\underline{w}$.

Second, suppose $\mu>\mu^{\circ}$. By (A4) and lemma 1, $w_{c}>\underline{w}$ and $c<0$. Any strategy $w_{n}>w_{c}$ is strongly dominated by $w_{n}=w_{c}$. In fact, suppose $w_{c}<w_{n}<w_{c}-c$; by result 2.B, $d=1$ and $\pi=v-\rho w_{c}-(l-\rho) w_{n}$, which is less than what the management would obtain by 
offering $w_{n}=w_{c}$. Suppose contrariwise $w_{n 2^{w}} c^{-c}$; by result $2 . \mathrm{B}, d=0$ and $\pi=v-w_{n}$, which is largest when $w_{n}=w_{c}-c$. However, this is clearly less than what the management would obtain by offering $w_{n} \in\left(w_{c}, w_{c}-c\right)$; in turn, this is strongly dominated by $w_{n}=w_{c}$. Whence, in a SPNE, $w_{n} \leq w_{c}$. Since $c<0$, by result 2.B, $d=1$ and $\pi=v-\rho w_{c}-(1-\rho) w_{n}$, which is largest when $w_{n}=\underline{w}$.

(B). Suppose $\underline{\mu}<\mu \leq \mu^{\circ}$. Any strategy $w_{n} \notin\left\{\underline{w}, w^{\wedge}\right\}$ is strongly dominated by either $\underline{w}$ or $w^{\wedge}$. In fact, suppose $w_{n}>\max \left(w^{\wedge}, w\right)$; by result $2 . \mathrm{B}, d=0$ and $\pi=v-w_{n}$, which is less than what the management would obtain by offering $w_{n}=\max \left(w^{\wedge}, w\right)$. Suppose contrariwise $w^{\wedge}>w_{n}>\underline{w}$ (other cases are not possible); by result 2.B, $d=1$ and $\pi=v-\rho w_{c}-(1-\rho) w_{n}$, which is less than what the management would obtain by offering $w_{n}=\underline{w}$. Whence, in a SPNE, $w_{n} \in\left\{\underline{w}, w^{\wedge}\right\}$. Suppose $w^{\wedge}(\mu) \leq \underline{w}$; then, in every SPNE, $w_{n}=\underline{w}$. Suppose contrariwise $w^{\wedge}(\mu)>\underline{w}$; if $w_{n}=w^{\wedge}$, by result 2.B, $d=0$ and management's payoff is $\pi^{\wedge}=v-w^{\wedge}=v-w_{c}+c$. If $w_{n}=\underline{w}$, by result 2.B, $d=I$ and management's payoff is written as $\underline{\pi}=v-\rho w_{c}-(1-\rho) \underline{w}$. Comparing the two expressions we obtain that $\underline{\pi}>\pi^{\wedge}$ if and only if $c<(1-\rho)\left(w_{c}-w\right)$, from which assert 3.B follows. QED

This result completes the characterisation of the unique SPNE of the model. Therefore, according to the extent of unionisation within the firm, three equilibrium paths may emerge, each identifying a specific pattern of wage formation. We discuss them in turn.

PROPOSITION 1. Suppose $0 \leq \mu \leq \underline{\mu}$. Along the equilibrium path, $w_{c}-w_{n}<c$ : the management pays the reservation wage and there is no local wage bargaining.

This is the most straightforward case: the firm's workforce is weakly unionised and therefore the threat of a strike is rather unimpressive. The union prefers to avoid the cost of bargaining, accepting whatever the management promises to pay. Thus, the management sets the wage rate at its minimum. This pattern of wage formation is therefore characterised by "management power". 
PROPOSITION 2. Suppose $\underline{\mu}<\mu \leq \mu^{\circ}$. Along the equilibrium path, the management promises to pay either the reservation wage or a higher wage. When the higher wage is offered, $w_{c}-w_{n}=c$ and there is no local bargaining. When the reservation wage is offered, a small union (such that $w_{c}-w_{n} \leq c$ ) accepts it, whereas a large union (such that $w_{c}-w_{n}>c$ ) tries to induce local bargaining.

Hence, when the union density lies within the intermediate range, three different patterns of wage formation can arise, depending on parameter values. When the density is relatively small, the situation is one of "management power". Otherwise, there may exist enough union members to increase the wage level by means of local negotiations, yet bargaining costs per union member are still important. In that case, the final outcome depends on the probability with which the union obtains recognition for bargaining. When this probability is relatively large, the management takes the union threat seriously and promises to pay a wage above the minimum. This makes wage negotiations look unattractive for the union, which prefers to avoid bargaining costs. This situation may be referred to as one of "cooperation". Note that in this situation the union threat is effective, i.e. the equilibrium wage is an increasing function of both union density and union bargaining power, even if there is no local wage bargaining. This is a specific implication of the threat hypothesis, which will be important for our empirical investigation.

When the probability of recognition is relatively small, the management does not take the union threat too seriously and sticks to pay the wage minimum. This opens the way to a situation of "conflict", which is similar to the one occurring when the union density is large.

PROPOSITION 3. Suppose $\mu^{\circ}<\mu \leq l$. Along the equilibrium path, $w_{c}-w_{n}>c$ : the management offers the reservation wage and the union seeks to obtain local wage negotiations. 
When union density is large, bargaining costs per capita are negligible, whereas social custom effects from collective action are important. Therefore, incentives for "cooperation" disappear and the union tries to obtain local wage negotiations. Extreme wage outcomes are predicted by the model: with a relatively large probability the union is recognised for bargaining and uses its large size as a means to induce a high wage; with a relatively small probability the union is not recognised and the management can stick to paying the minimum wage.

\section{The Empirical Specification}

In this section we derive an empirical specification, suitable for estimation, for the model presented above. Following the structure of the bargain previously discussed, we shall first specify the stage in which the union decides, conditional on firm's wage offers, whether to ask for wage bargaining at the local level or not. In the subsequent stage, wage bargaining may take place and different wage formation regimes are observed.

It is important to note that, in our model the determination of the wage formation regime is the result of actions taken noncooperatively by agents in order to maximise their payoff function. In this respect the present investigation differs from those studies in which the determination of the wage formation regime is taken as exogenously given (Freeman and Medoff, 1981; Blanchflower, 1984; Stewart, 1987; Dell'Aringa and Lucifora, 1992). Hence, in the following analysis we specify an endogenous switching regression model and apply the methodology outlined in Lee (1978), and in Duncan and Leigh $(1980,1985)$ to estimate separate wage determination equations. Typically, in this class of models, a switching equation is used to allocate wage setting units to different regimes according to some form of utility maximisation procedure, and then wage equations are estimated. In our case, the choice criterion will be concerned with the existence of formal local wage bargaining agreements or not. 
Let $w^{c}$ be the wage outcome under local bargaining in the $i$-th plant (equal to the larger of the Nash solution and the reservation wage), let $w_{i}^{n}$ be the wage observed in the $i$-th plant where no bargaining occurs (equal to the reservation wage or set at a higher level) and let $c_{i}$ be the cost of bargaining in each establishment. According to result 2, the local union will try to induce wage bargaining provided that,

$$
w^{c}{ }_{i}-w_{i}^{n}>c_{i}
$$

Defining $\delta_{i}^{*}$ as the indicator of the union trying to induce local wage negotiation and rearranging [2] we can write,

$$
\delta_{i}^{*}=\ln w_{i}^{c}-\ln w_{i}^{n}-C_{i}
$$

where $C_{i} \equiv c_{i} / w^{n}{ }_{i}$ and the choice criterion becomes $\delta^{*}>{ }_{i}$. Thus the probability of a local union asking for plant level wage negotiations will depend positively on the wage outcome it expects from bargaining, and negatively on both firm's wage offers and bargaining costs.

Equation [3] forms the basis of our switching equation. Since $\delta^{*}{ }_{i}$ is a latent variable - in that it is not directly observable - it has to be estimated. Also, since we do not observe the wage outcome that the $i-t h$ plant, covered by formal wage agreement, would have had in the absence of local bargaining, we need to specify the wage functions for each of the two wage setting regimes:

$$
\begin{gathered}
\ln w^{c}{ }_{i}=X_{i} \beta^{c}-\varepsilon^{c}{ }_{i} \\
\ln w^{n}{ }_{i}=X_{i} \beta^{n}-\varepsilon^{n}{ }_{i}
\end{gathered}
$$

where $X_{i}$ is a vector of characteristics that influence wage levels in the $i$-th plant, $\beta^{c}$ and $\beta^{n}$ are vectors of parameters to be estimated and, $\varepsilon^{n}{ }_{i}$ and $\varepsilon^{c}{ }_{i}$ are the disturbance terms ${ }^{8}$. Finally, the net costs of bargaining can be specified as follows:

7 Rewrite [2] as: $w^{c}{ }_{i}-w^{n}{ }_{i}\left(l+C_{i}\right)>0$. Define, $d_{i} \equiv \ln \left(w^{c}{ }_{i} / w^{n}{ }_{i}\left(l+C_{j}\right)\right) \cong \ln w_{i}^{c}-\ln w^{n}{ }_{i}-C_{i}$, as in [3]. It is worth noting that average bargaining costs have been specified as being proportional to the nonbargained wage. Although this specification is mainly adopted for functional convenience, nevertheless, there are some theoretical justifications which may explain its employment here. In particular, since part of bargaining costs essentially arise from the organising activity of union's officials, it might not be unreasonable to assume them to be proportional to the wage paid in the non-bargaining sector, - i.e. taken as indirect measure of the opportunity cost of time of union's officials. 


$$
C_{i}=\boldsymbol{H}_{i} \gamma+v_{i}
$$

where $\boldsymbol{H}_{i}$ includes a set of establishment and union's characteristics that affect bargaining costs, $\gamma$ is a vector of parameters to be estimated and $v_{i}$ is the error term.

The substitution of equations [4], [5] and [6] into [3] yields the reduced form switching function,

$$
\delta^{*}{ }_{i}=X_{i}\left(\beta^{c}-\beta^{n}\right)-H_{i} \gamma+\left(\varepsilon^{c}{ }_{i}-\varepsilon^{n}{ }_{i}-v_{i}\right) \equiv W_{i} \Pi-\kappa_{i}
$$

where $W_{i}$ includes both vectors of variables $\boldsymbol{X}_{i}$ and $\boldsymbol{H}_{i}$ and $\Pi$ contains the vectors of parameters, $\beta^{c}, \beta^{n}$ and $\gamma$. The disturbances, $\varepsilon^{c}{ }_{i}, \varepsilon^{n}{ }_{i}$ and $v_{i}$ are assumed to be joint normally distributed with means zero and covariance matrix $\Sigma^{9}$. However, $\delta^{*}{ }_{i}$ is not directly observed, what is observed is its dichotomous realisation $\delta_{i}$. Hence, $\delta_{i}=1$ if $\delta_{i}^{*}>0$ and $\delta_{i}=0$ if $\delta_{i}^{*}<0^{10}$.

Equations [4], [5] and [7] are the basic equations of our empirical analysis. In order to estimate the model we have to take into account both the endogenous nature of the regime switching process and the truncation problems associated with selectivity'l. Following standard practice we estimate the model in two stages: in the first stage, we use the probit method to get an estimate of $\Pi$, next we estimate wage equations for each regime correcting for selectivity bias (Heckman, 1979; Maddala, 1983)12. It is worth

8 Note that wage equations [4] and [5] cannot be estimated by standard methods, as observed wage outcomes are conditional on the realisation of a particular wage setting regime. In practice, both equations have to be estimated on truncated samples, since for equation [4] it is:

$$
E\left(\ln w^{c}{ }_{i} \mid X_{i}, \delta>0\right)=X_{i} \beta^{c}+E\left[\varepsilon^{c}{ }_{i} \mid \delta>0\right]
$$

and similarly, considering $\delta<0$, in equation [5].

9 As shown in Lee (1978), in order to identify the parameters of the model, it is necessary to set the variance of the error term of the reduced form switching equation $\left(\sigma^{2}{ }_{k}\right)$ equal to one, and to assume a joint normal distribution.

10 The fact that in the theoretical model $d_{i}=1$ is equal to $\delta_{i}=1$ up to a probability $\rho_{i}$, can be easily accommodated in [7] simply adding an extra term to the error term $\kappa_{i}$.

${ }^{11}$ Models of selectivity, of the type proposed here, have been analysed in various context applied to different economic problems, like, education (Willis and Rosen, 1979), housing (Lee and Trost, 1978), migration (Robinson and Tomes, 1982), and - as in the present context - union and wages (Lee, 1978).

12 In order to get consistent estimates of $\beta^{c}$ and $\beta^{n}$, wage equations [4] and [5] have been estimated as follows,

$$
\begin{aligned}
& E\left(n w^{c} \mid X_{i}, \delta>0\right)=X_{i} \beta^{c}-\sigma_{c \mathrm{~K}}\left[\phi\left(W_{i} \Pi \mathrm{L}\right) / \Phi\left(W_{i} \Pi\right)\right] \\
& E\left(\ln w^{n}{ }_{i} \mid X_{i}, \delta<0\right)=X_{i} \beta^{n}+\sigma_{n \mathrm{~K}}\left[\phi\left(W_{i} \Pi\right) / 1-\Phi\left(W_{i} \Pi\right)\right]
\end{aligned}
$$

where $\phi(\cdot)$ and $\Phi(\cdot)$ are the hormal density function and cumulative distribution function respectively. The second term on the RHS in [4'] and [5'] is often referred to as the Inverse Mills-Ratio (IMR). 
noting that the existence of selectivity bias, between wage setting regimes, might be taken as indication of the endogenous nature of the "bargaining vs. no-bargaining" decision of the local union. Results obtained applying this methodology of analysis are reported in column 3 and 4 of tables 2 and 3.

A questionable aspect of the endogenous switching approach is related to the assumption of normality for the error term in the reduced form choice equation (i.e. $\kappa_{i}$ in equation [7]). Duncan and Leigh (1985) developed an alternative estimation procedure, based on an instrumental variables (IV) approach, which does not require any restriction on the distribution of the error term. Following their methodology, we shall consider also the following two-stage estimation method: in the first stage, equation [7] is estimated by probit methods and the probability that the local union will ask for local wage bargaining is retained. In the second stage, these probabilities are interacted with the vector of characteristics for both bargaining and non-bargaining regimes (i.e. the $\boldsymbol{X}_{i}$ variables) as to form instruments. In particular, writing the $\log$ of observed wages as,

$$
\ln w_{i}=\delta_{i} \ln w^{c}{ }_{i}+\left(1-\delta_{i}\right) \ln w^{n}{ }_{i}
$$

and substituting [4] and [5] in [8] yields,

$$
\ln w_{i}=\left(\delta_{i} X_{i}\right) \beta^{c}+\left[\left(1-\delta_{i}\right) X_{i}\right] \beta^{n}+\left[\delta_{i} \varepsilon_{i}^{c}+\left(1-\delta_{i}\right) \varepsilon^{n}{ }_{i}\right]
$$

and rearranging,

$$
\ln w_{i}=Z^{c} \beta^{c}+Z^{n} \beta^{n}+\psi_{i}
$$

where $Z^{c_{i}}=\delta_{i} X_{i} ; Z^{c}{ }_{i}=\left(1-\delta_{i}\right) X_{i}$, and $\psi_{i}=\left[\delta_{i} \varepsilon^{c_{i}}+\left(1-\delta_{i}\right) \varepsilon^{n}{ }_{i}\right]^{13}$. The instruments used to estimate equation [10] are the expected values of the explanatory variables,

$E\left(Z^{c}{ }_{i}\right)=p^{\wedge}{ }_{i} X_{i}$ and $E\left(Z^{n}{ }_{i}\right)=\left(1-p^{\wedge}\right) X_{i}$, where $p^{\wedge}{ }_{i}$ are the predicted probability obtained from equation [7]. The specification adopted in [10] can also be used to test the validity of

13 As shown in Duncan and Leigh (1985), the error terms in the wage equations must be identical. Hence, the joint density functions $f\left(\psi_{i}, \varepsilon^{c}\right)$ and $f\left(\psi_{i}, \varepsilon_{i}^{n}\right)$ - in the different wage regimes - should underline the same error generating process. However, this might be considered less restrictive than the normality assumption. 
the endogeneity assumption for the different wage setting regimes, by means of an Hausman (1978) test $\mathrm{t}^{14}$.

The specification of the wage functions for the different pay setting regimes will follow closely the implications outlined in the theoretical model. In particular, building on results 1 and 3 , we can specify the vector of variables $X_{i}$, in equations [4] and [5], as follows,

$$
\boldsymbol{X}_{i}^{k}=\left\{\mu_{i}, \alpha_{i}, \underline{w}_{j}, v_{i}, s, \boldsymbol{Y}_{i}\right\} \quad k=c, n
$$

where most variables maintain their former meaning, and $\boldsymbol{Y}_{i}$ represents a vector of exogenous variables that may influence the wage in the $i$-th plant. First, a variable measuring union membership at the establishment level is considered $\left(\mu_{i}\right)$. We compute this variable as the proportion of unionised workers over total employment in the establishment (UDENS). Second, we include a proxy for union bargaining power $\left(\alpha_{i}\right)$. In particular, in the present framework, union power in wage determination arises from the existence of different discount factors between bargainers, which enables one side to impose costs on the other side by forcing a delay in the agreement. The practice of collective action of organised workers is the traditional way of achieving it. The average number of hours lost in a strike per unionised worker are used as a proxy for bargaining power (HRSTR $)^{15}$. Third, the alternative wage $\left(\underline{w}_{j}\right)$ - that could be earned by workers outside the plant - is measured by the logarithm of minimum contractual wage prevailing in the $j$-th sub-industry in which the plant operates (LWALT) ${ }^{16}$. It is worth noting that, since

14 Following Duncan and Leigh (1985), and Addison and Portugal (1989) the Hausman test can be calculated augmenting equation [10] with a set of instruments $\left[Z^{\wedge}{ }_{i}, Z^{\wedge}{ }_{i}\right]$. These, however, are calculated as predicted interaction between observed union status and the $X_{i}$ vector, $\ln w_{i}=Z^{c}{ }_{i} \beta^{c}+Z_{i}^{n} \beta^{n}+\gamma\left[Z^{\wedge}{ }_{i}, Z^{\wedge}{ }_{i}\right]+\zeta_{i}$.

where $\mathrm{H}_{0}: \gamma=0$ is the hypothesis to be tested.

15 Some authors have argued that the occurrence and the length of strikes might not be independent from the wage determination process (see, Geroski, et al., 1982). Since, in the present study, no attempt have been made to model strike activity jointly with wage formation, the "ability to strike" is assumed to be exogenous. Also, although, the theoretical model seem to suggest the inclusion of a variable measuring the ability to prolong a strike - i.e. the average length of strikes, rather than total hours lost -, it should be noted that it is common practice for Italian trade unions to have many short "wild cat" strikes during the same industrial dispute.

16 Alternatively, outside options can be specified as reflecting the average local wage level. In this case, low geographical mobility rather than specific (to the sub-industry) human capital considerations is important. Both specifications are experimented in the empirical analysis. 
in the Italian context strike pay is likely to be the same for all unionised workers, no effect on wages is estimated. Finally, several control variables measuring (average) labour productivity $\left(v_{i}\right)$ and other factors that - ceteris paribus - are likely to affect wages $\left(\boldsymbol{Y}_{i}\right)$ are included in the estimated wage equations. In particular, the proportion of manual workers (MANPC), females (FEMPC), part-timers (PARTPC) and workers in shift-work (SHIFTPC) have been tested ${ }^{17}$. Also, three firm size dummies and six sub-industry dummies have been used as control variables in the wage equations.

The costs of bargaining, as specified in the theoretical model, are likely to depend on union membership, the firm's characteristics and bargaining practices in the plant. Therefore we can specify the vector of variables $H_{i}$ in equation [6] as follows,

$$
\boldsymbol{H}_{i}=\left\{\mu_{i}, \varphi_{i}, \boldsymbol{B}_{i}\right\}
$$

where, $\mu_{i}$ is defined as discussed above, $\varphi_{i}$ is a vector of establishment size dummies and $\boldsymbol{B}_{i}$ is a vector of bargaining arrangements in the plant. Note that the variables contained in the $B_{i}$ vector are not included in the wage equations, as they are likely to have an impact on the costs of bargaining and hence on the wage determination regime, without (directly) affecting wage levels ${ }^{18}$. Thereby we introduce a variable indicating the proportion of establishments - in each sub-industry - with a formal bargaining agreement in force, which measures the coverage of decentralised bargaining (COVAZ). It can be argued that the larger is the number of establishments where decentralised bargaining already takes place, the lower is likely to be the net cost, for the local union in the $i$-th establishment, of conducting wage bargaining with the management. Furthermore, we include a dummy variable indicating whether multiple unions in the plant are characterised by cooperative relations in their bargaining activity (JNEG) ${ }^{19}$. Finally, a dichotomous

17 Both PARTPC and SHIFTPC variables never appeared to be statistically significant in estimated regressions, therefore they have not been included in our preferred specifications.

18 It should be stressed that in the empirical model the Bi vector has an influence on wage determination only through the increased probability of observing local bargaining, as a result of lower costs. Although this restriction is not necessary for the identification of the switching equation, it can improve the robustness of the estimations. Experimentations, however, showed that results are not significantly modified by its exclusion.

19 In Italy, the presence of multiple unions in each establishment is the norm. However, unions may choose to bargain jointly with company management. In the metal mechanical engineering sector the presence of the FLM union indicates the existence of a federation of unions. 
variable indicating whether a formal local wage agreement is in force (CONTR), represents our observed wage bargaining regime indicator.

A more detailed description of the variables and their means is presented in the appendix.

\section{The data}

The data source used in the empirical analysis is the 1990 Federmeccanica survey on pay and labour conditions. It is based on a sample of 3,000 establishments of the Italian metal-mechanical engineering industry. Taking into account both geographical distribution and size of establishments (even very small firms are included), it is a nationally representative sample of the industry considered.

The survey provides detailed information on pay levels and bargaining arrangements. Several indicators of union presence, union behaviour and the firm's characteristics are available. The wage variable is defined as average gross yearly earnings of blue-collar workers, and includes base rate pay, local bargaining premia and other bonuses ${ }^{20}$.

Table 1 reports some descriptive statistics for selected variables in the sample, disaggregated by wage bargaining arrangements (i.e. with and without a local formal agreement) and broken down into several union density intervals ${ }^{21}$. A first remark concerns the distribution of establishments according to union membership: in the regime without formal local wage agreements, establishments tend to be concentrated $(58 \%)$ in the lowest union density interval; conversely, where formal local wage agreements exist, establishments are found in the upper portion of the union density distribution. Considering plant size, it can be noted that establishments where decentralised wage bargaining is

20 Since the data set does not provide an accurate measure of hours worked, yearly wages are used. However, in order to control for wage variations arising from differences in hours worked, overtime premia have been excluded and several control variables proxying for differences in hours worked have been considered (i.e. proportion of part-timers, proportion in shift-work, etc.).

21 The breakdown presented for the union density variable has been tested on the wage variable comparing sample means. 
observed are on average larger. In other words, the probability of finding a formal local wage agreement seems to be increasing with both firm size and union density.

Some additional features of the data set can be explored by looking at raw averages. Blue-collar wages are generally increasing in union density irrespectively of whether decentralised bargaining takes place or not ${ }^{22}$. The proportion of manual workers and the proportion of females over total employment in the plant show, respectively, a positive and a negative correlation with union density. This is a common finding of studies which analyse the patterns of unionisation, namely it suggests that manual workers tend, on average, to be more unionised, while females are less likely to be so. It also might be indicative of the organisation of work within establishments: with more traditional production technologies being characterised by a higher proportion of manual workers and a lower proportion of females.

\section{Results}

In this section we report the main sets of empirical findings. Table 2 presents the estimates of the reduced form switching equation. In order to check the sensitivity of the estimation method chosen, both probit and logit models were tested and results are reported for comparison purposes. The statistical significance of parameter estimates and their signs do not appear to be influenced by the estimation method used and generally accord with theoretical implications. Predicted probabilities used to allocate establishments into the bargaining and no-bargaining regimes, were also very similar in both cases ${ }^{23}$. In

22 In table 1, at very-high union density levels (81-100\%) - in establishments where local wage bargaining is observed - wages exhibit a modest decline. Although, this evidence might at first appear rather puzzling, it can be explained taking into account the relatively small size of establishments included in the high density group.

23 The resulting sample split according to predicted probabilities is as follows: for the probit case, 291 establishments with formal local agreements (i.e. CONTR=1) - out of the 1612 - were allocated to the nobargaining regime, conversely 304 establishments with no bargaining arrangements (i.e. CONTR=0) - out of the 1204 - reported were allocated to the bargaining regime. For the logit case, 222 establishments with formal local agreements were allocated to the no-bargaining regime, conversely 361 establishments were allocated to the alternative bargaining regime. 
practice, probit coefficients were used to select establishments into the predicted bargaining regime, and to compute both selectivity variables (for the IMR method) and instruments (for the IV method).

The coefficients from the reduced form probit equation (i.e. column 1 in table 2) indicate the impact of exogenous variables on the probability of decentralised bargaining occurring; this follows both via the wage differential and the cost of bargaining. As far as the determinants of the latter are concerned, we find a positive and statistically significant effect of union density on the probability of bargaining. Establishment size dummies exhibit a monotonically increasing pattern, thus indicating that large sized plants have a higher probability of enforcing local bargaining. Although, the variable measuring the coverage of decentralised bargaining bears a positive sign, it is never statistically significant. Conversely, the fact that multiple unions in the plant are characterised by cooperative relations shows a positive impact on the likelihood of bargaining. These results suggest that bargaining costs are indeed important determinants of the probability of bargaining.

A second route through which local bargaining activity is influenced occurs via the union wage mark-up, hence all variables affecting its size are included to complete the specification of our switching function. Further results show that the probability of finding a formal local bargaining arrangement is significantly reduced if the establishment is characterised by a large proportion of manual workers, if female employment is high (though the latter is not statistically significant), and also if the location is in the south of Italy. Better outside opportunities, in terms of higher alternative wages, show a negative impact on the probability of bargaining - as they reduce the union mark-up - the effect, however, is not statistically significant. Finally, the variable measuring the level of collective action per organised worker in the establishment enters with a significant positive coefficient. No statistically significant differences in the probability of bargaining seem to exist among different sub-industries, within the metal-mechanical sector ${ }^{24}$.

24 Some recent studies for the UK have shown that the probability of 'union recognition' for collective bargaining purposes is an historically determined feature of the establishment, rather than a strategic aspect which can change frequently according to the balance of power between unions and management as in a continuously played game (Gregg and Naylor, 1990; Disney et al., 1993). The idea is that once a union is set up for bargaining in an establishment, it is very difficult for the management to refuse to 
The estimation results of the wage equations, for both bargaining and no-bargaining wage determination regimes, are presented in table 3 and 4 (columns 1, 3, 5, and 2, 4, 6, respectively). The first two columns, of each table, contain the estimates obtained using simple OLS methods, columns 3 and 4 show the results of the IMR model, finally, columns 5 and 6 report the estimates of the IV model. In table 4 a more direct test of our union threat model is performed, as union membership dummies are included in order to capture the implications of propositions 1 to 3 of the theoretical section. In general, results obtained using different estimation methods do not change substantially the qualitative picture; however, it will be shown that simple OLS methods cannot account adequately for the strategic decision involved in the wage determination process under union threat effects.

Table 3 records the estimates of the model specified with a continuous and linear union density variable. As expected, the two proxies included for average labour productivity in the establishment, namely the proportion of manual workers (MANPC) and the proportion of females (FEMPC), enter the wage equation with a negative sign. In other words, a lower stock of human capital (as measured by the included variables) seems to reduce average pay in the establishment. It should be noted, however, that these variables might be capturing also other effects: first, a structural characteristic of the plant, i.e. a high proportion of manual workers is likely to be found where the capital-labour ratio is low and there is moderate technological innovation; second, gender discrimination effects, i.e. women are, ceteris paribus, paid less than men. It can be noted that the depressive effect on blue-collar wages is stronger in establishments where a formal local wage negotiate with it. Disney et al. (1993) suggest - and provide empirical evidence - that the characteristics of the establishment "when it was set up" are a key determinant of the probability of 'current' recognition. Though it would be interesting to test whether the same "hysteresis" effect is repeated in Italy as well - lack of data hinder such investigation -, it should be noted that decentralised bargaining in Italy takes place after that centralised collective negotiations have set the guidelines for national sectoral wage agreements and, only at this stage, conditional on establishment performance, management behaviour and union strength, a formal local contract is eventually signed. Also, it can be stressed that the absence of any formal employer recognition for bargaining purposes, leaves considerable flexibility to negotiating parties in decisions concerning the opportunity to have (or not) additional bargaining at the establishment level. In conclusion, it can be argued that the structure of local bargaining agreements, in Italy, is likely to follow more closely the structure of a repeated game between unions and employers, hence the omission of the "historical" determinants of the probability of bargaining should not be regarded as a serious misspecification of the switching equation. 
agreement is in force than elsewhere. Since one would expect that unions reduce (rather than increase) returns to average labour productivity, this result might suggests that structural features of the plant and gender discrimination effects are relevant ${ }^{25}$. As expected, given the huge differences existing in general economic conditions between the north and the south of Italy, the location of the establishment in the southern regions of the country (SOUTH) shows a negative impact on wages. The smaller effect detected in establishments with a formal local wage agreement (i.e. as opposed to establishments where no wage bargaining takes place) might be taken as evidence that unions' policies are aimed at insulating workers from the external labour market conditions. This result is reinforced by looking at the effects of the alternative wage (LWALT) on blue-collar pay in bargaining and no-bargaining regimes. While, average pay in establishments not covered by a local wage agreement shows an elasticity of 0.7 with respect to the alternative wage, the estimates in establishments covered by a local wage agreement are close to zero and never statistically significant. Parameter estimates for sub-industry dummies indicate the existence of some sectoral dispersion in wage levels within the metal-mechanical sector itself $^{26}$. The results discussed up to this point apply with minor differences to all estimation methods used. In general, parameter estimates are slightly larger, as compared to OLS, when the endogenous feature of the bargaining process is taken into account by means of IMR or IV methods, thus suggesting that results obtained with standard methods might slightly underestimate the actual effects on pay.

A major difference between OLS and alternative estimation methods is found by looking at the results on establishment size (D2, D3). Whilst it is generally confirmed that larger establishments pay, on average, higher wages, the methods based on the endogenous switching function (i.e. predicted probabilities are used for the regime split) allocate all plants with more than 100 employees (i.e. D3) to the wage bargaining regime, leaving the

25 Other variables proxying for job conditions, such as part-time work and shift work, were experimented but since they never proved to be statistically significant have not been included.

26 Estimates of sub-industry dummies are always jointly statistically significant and, in some cases, they are also significant individually. 
large size group, in the no-bargaining regime, empty ${ }^{27}$. This is mainly due to the fact that the predicted probability of finding a formal local wage agreement in a large plant is very high.

Finally, the distinguishing implications of the union threat hypothesis are tested, namely the positive relationship between the wage level and both union density and union bargaining power in establishments not covered by a formal local wage agreement (see result 3 , in section 2 ). The variable proxying union bargaining power (HRSTR) shows a positive impact on wages in both regimes, although it is not statistically significant in the no-bargaining sector. Estimates of the effects of local union density (UDENS) on bluecollar wage levels indicate that in establishments where a larger proportion of the workforce is unionised the average pay level is higher ${ }^{28}$. As predicted by the theoretical model, a positive impact of union membership on pay is also detected in establishments where a formal local wage agreement is not observed ${ }^{29}$. Hence, union threat effects seem to induce employers to respond to the threat of greater union strength (i.e. an increase in union density) by raising wage levels. In other words, employers anticipate the possibility that a stronger union might be more successful (and powerful) in conducting local wage negotiations and, therefore, try to increase the opportunity cost - for the local union - of organising the workforce for collective bargaining. Furthermore, results show that the elasticity of union density with respect to wages (evaluated at mean values) is higher in establishments where a formal local wage agreement exists, thus suggesting that union ability to impose costs onto employers - as one might expect - is more pronounced where workers are already organised for bargaining purposes ${ }^{30}$.

27 For this reason no parameter estimates are reported in table 3 and 4 (columns 4 and 6 ) for the dummy variable $\mathrm{D} 3$ in the no-bargaining regime.

${ }^{28}$ This result confirms pervious evidence on the effects of unionism on wages, as it suggests that a stronger union will, ceteris paribus, obtain a larger mark-up (Stewart, 1987; Dell'Aringa and Lucifora, 1992).

29 A specific feature of the Italian industrial relations setting is that local bargaining may take places at any time between any two national collective agreements ( 3 years length). In this respect, it should be noted that although we use cross-sectional data (as to the situation of establishments in 1990), as far as local bargaining agreements are concerned, retrospective information on whether a contract was signed in previous years is also available. Controlling for this, rules out the possibility that we interpret as "union threat effect" the impact of formal contracts that were signed before our investigation period. Moreover, Dell'Aringa and Lucifora, (1992) show that local contracts have no lasting effects on wages, when a new national collective agreement is signed.

30 The elasticities of union density with respect to wages (evaluated at mean values) are as follows: 
Is, however, the threat posed by unionised workers (either under a formal wage agreement or not) credible for any level of membership? Our theoretical model suggests that this is not the case, as the effects on wage levels are likely to vary according to the level of union density, thus producing different patterns of wage formation. In table 4 , we allow for more flexible specifications of the effect of union density over wages. In particular, after testing down from a more general specification, we end up with a partitioning of the union density variable into four different categories: (i) no-union members (our reference category), (ii) low union density (UDENS1- below 30\% unionisation in the establishment), (iii) average union density (UDENS2 - between $30 \%$ and $70 \%$ ), and high union density (UDENS3 - over 70\%) ${ }^{31}$.

Results seem to be in line with theoretical predictions. At a low density level no statistically significant effects of unions on wage levels are detected in either the bargaining or the no-bargaining regime, suggesting that - even if formal bargaining occurs - local unions cannot carry on a credible threat of collective action. Conversely, when the local union is capable of organising a larger proportion of the workforce average wages are significantly higher - in both wage determination regimes - as compared with situations where unions are weak, or not present. Establishments characterised by average union density and a formal wage agreement pay, on average, nearly $8 \%$ more than similar establishments with relatively few union members. The wage premium is reduced by a half if no formal bargaining agreement exists (see columns 3 to 6 , in table 4 ) 32 .

Quite interestingly, while in establishments with a high union density, if a formal wage bargaining agreement is in force, a wage premium of nearly $10 \%$ is found; no effects on wage levels are detected in the absence of such agreements. Although, at first, it might appear puzzling to find no effects on wages at high union density levels, it should be

(OLS) $\eta^{\mathrm{c}}=0.022, \eta^{\mathrm{n}}=0.015 ;$ (IMR) $\eta^{\mathrm{c}}=0.061, \eta^{\mathrm{n}}=0.024 ;$ (IV) $\eta^{\mathrm{c}}=0.039, \eta^{\mathrm{n}}=0.027$.

31 The initial specification contained 10 dummy variables for different union density intervals. The validity of the more parsimonious specification presented in table 4 has been tested by means of linear restriction on the equality of estimated parameters.

32 It can be noted that endogenous selection estimates (i.e. IMR and IV), as compared with simple OLS estimates, show a larger impact of union density on wage levels. Therefore, it can be argued that existing empirical evidence which did not correct for selectivity effects is likely to underestimate the true effect of union density on wage level. 
considered that once the conflict over the bargaining vs. no-bargaining issue between the firm and the local union is over, the optimal strategy for the firm is to pay the reservation wage (see proposition 3 , in section 2$)^{33}$. Since remainder parameter estimates do not differ substantially from results already presented, we shall omit a further detailed discussion here.

A final comment concerns the issue of endogeneity. As described in section 3 , the IMR and the IV methodology allow direct testing of the selectivity hypothesis. We shall consider them in turn. Our estimates for the SELECT variables in both the bargaining and the no-bargaining wage equations are statistically different from zero, thus suggesting that selectivity is an important phenomenon in local bargaining decisions. In particular, the negative sign detected in the bargaining wage equation (i.e. CONTR=1) indicates that workers employed in those establishments where formal local bargaining occurs have, on average, better earnings conditions in that regime, than workers employed in an establishment randomly chosen from the whole sample. Similarly, the positive sign detected in the no-bargaining wage equation (i.e. CONTR $=0$ ) suggests that workers employed in those establishments where no formal local bargaining occurs are, ceteris paribus, in a better position than any other worker employed elsewhere. Results from Hausman's test statistics confirm the above conclusions for the IV estimation methodology. In other words, the hypothesis of local bargaining decisions being exogenously determined is strongly rejected by the data ${ }^{34}$.

33 Note that OLS estimates differ in this respect. This is mainly due to the fact that, if endogenous selectivity is not considered the bias in parameter estimates is likely to be larger the higher is union density; since the latter is among the main determinants of the probability of observing local bargaining. 34 The Hausman test statistics gave the following results: $F(26,2788)=22.6$ (as in table 3 ); $F(32$, 2780 ) $=28.1$ (as in table 4). All significant at the 1 percent level. 


\section{Concluding remarks}

In this paper we have developed a game-theoretical formulation of wage setting under union threat effects and tested it using establishment-level data for the Italian metalmechanical engineering industry.

Our theoretical analysis differs from Dickens (1986), in that we are able to characterise various wage formation patterns that may arise in the SPNE, while only the case where the firm decides to avoid collective bargaining was previously considered. Thus, in firms with low union density we have shown that the union's threat of collective action is ineffective and firms pay the reservation wage. Conversely, for intermediate density levels, the union threat turns out out be effective: firms come close to matching union wages although no local wage negotiation might occur. The union threat is again ineffective for high levels of union density. In this case, firms can either stipulate a collective wage agreement, or merely pay the reservation wage. The local union density level drives these results through its effects on both the firm's disagreement point in bargaining, and the net bargaining cost per union member. Furthermore, it determines the probability of observing local wage bargaining, conditioned on the union's willingness to negotiate.

Given the possibility of a union threat effect, as shown by the theoretical investigation, its relevance for actual wage setting behaviour is investigated and validated empirically. Wage formation under union threat is analysed for the Italian metal-mechanical engineering industry using micro-data on pay levels and bargaining arrangements for a representative sample of approximately 3,000 establishments.

Following the theoretical model, we have adopted an empirical specification which allows to take into account the endogenous nature of the occurrence of local wage bargaining. A switching equation model is then used and the existence of selectivity bias tested therein.

Our main set of results confirms the implications of the theoretical model. The hypothesis of local bargaining decisions being exogenously determined is strongly rejected 
by the data. Moreover, we find strong empirical support for the existence of different wage formation patterns - as described in the theoretical model - according to local union density levels. In particular, our main findings - for the industry under examination - suggest that no statistically significant effects of unions on wages exist at low union density levels Conversely, where a larger proportion of workforce is organised by trade unions average wages are significantly higher, as compared with situations where unions are absent or weak, under both bargaining and no-bargaining wage determination regimes. Finally, in establishments characterised by a high union density, the effect of unions on wages is very high if a formal agreement is signed, while it is close to zero if the agreement is not reached.

In conclusion, the paper offers some interesting insights on the effects that different patterns of unionisation might have on the structure of relative wages: first, the importance of local union strength (i.e. union density) in determining the outcome of decentralised wage bargaining is confirmed by our results; second, the role that strategic elements play in wage formation under unionism is shown to be relevant for an adequate characterisation of the bargaining process. 
Table 1 - $\quad$ Means for Selected Variables by Union Density (establishments with formal local wage agreements)

\section{Union density}

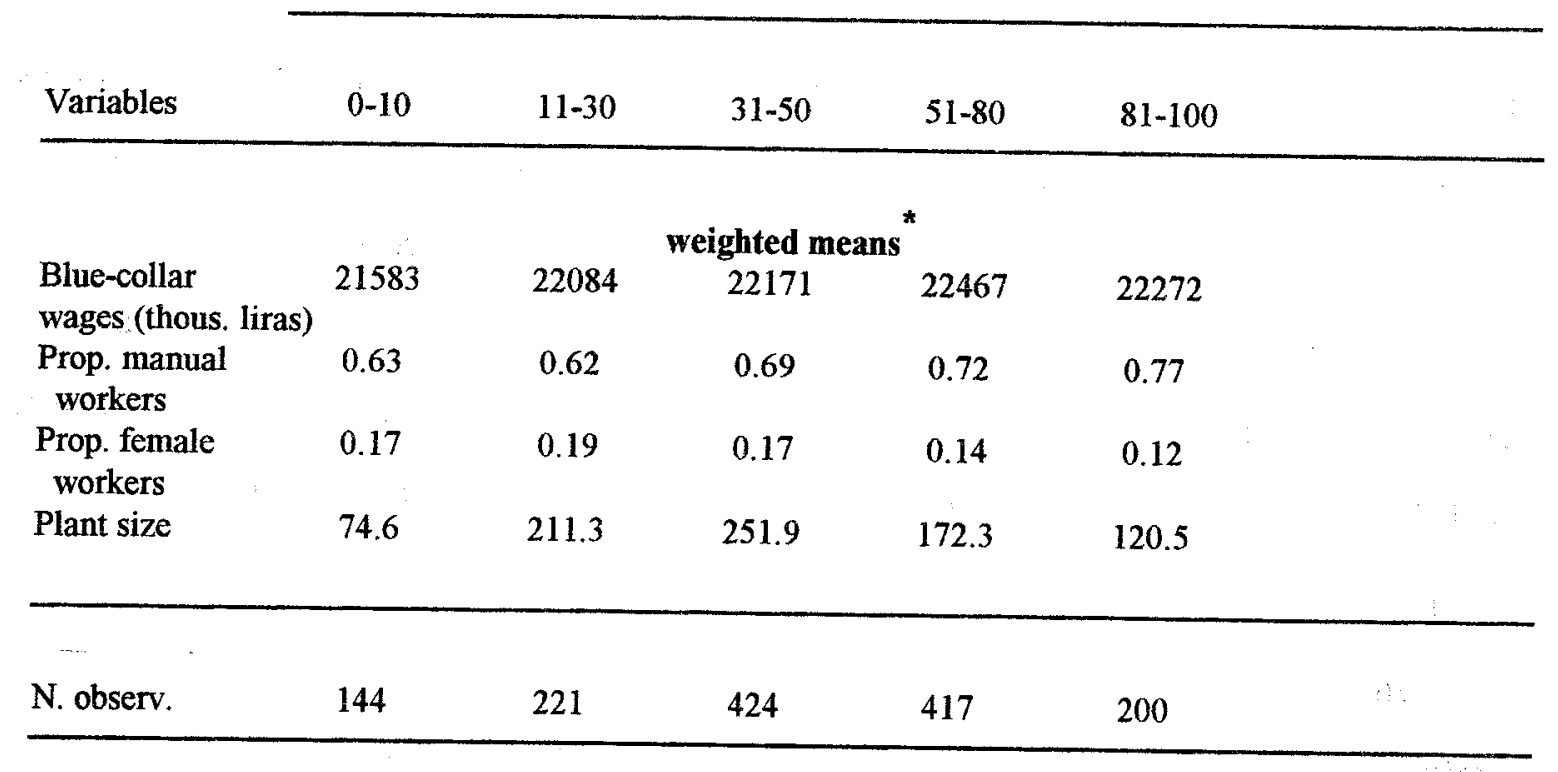

\section{Means for Selected Variables by Union Density} (establishments without formal local wage agreements)

\section{Union density}

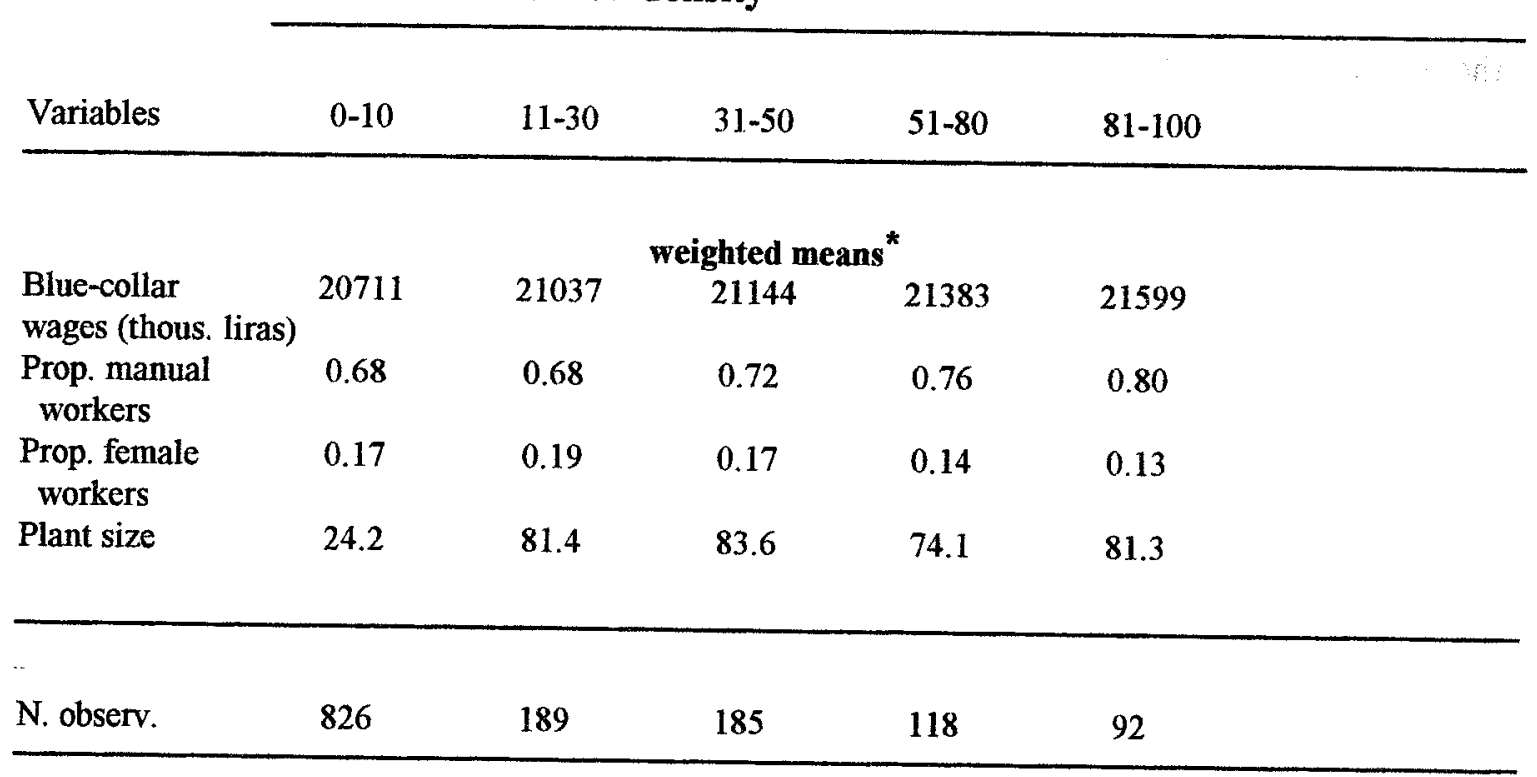

note: * weighted by the number of employees in the establishment 
Table 2 - Estimated Coefficients for the Switching Function

Variables $\quad$ Reduced Form Coefficients Estimates

Probit (1) Logit (2)

\begin{tabular}{|c|c|c|c|}
\hline UDENS & $\begin{array}{c}2.2168 \\
(0.1116)\end{array}$ & $\begin{array}{l}3.8218 \\
(0.2026)\end{array}$ & \\
\hline $\mathrm{D} 2$ & $\begin{array}{c}0.5591 \\
(0.0774)\end{array}$ & $\begin{array}{l}0.9300 \\
(0.1313)\end{array}$ & \\
\hline $\mathrm{D} 3$ & $\begin{array}{c}1.1492 \\
(0.0870)\end{array}$ & $\begin{array}{l}1.8981 \\
(0.1640)\end{array}$ & \\
\hline COVAZ & $\begin{array}{c}0.7574 \\
(1.0374)\end{array}$ & $\begin{array}{l}1.4594 \\
(1.7849)\end{array}$ & \\
\hline JNEG & $\begin{array}{c}0.2945 \\
(0.0829)\end{array}$ & $\begin{array}{l}0.3951 \\
(0.1483)\end{array}$ & \\
\hline MANPC & $\begin{array}{l}-0.5254 \\
(0.1704)\end{array}$ & $\begin{array}{l}-0.8494 \\
(0.2929)\end{array}$ & \\
\hline FEMPC & $\begin{array}{l}-0.0029 \\
(0.1857)\end{array}$ & $\begin{array}{l}-0.0448 \\
(0.3212)\end{array}$ & \\
\hline SOUTH & $\begin{array}{l}-0.5722 \\
(0.1545)\end{array}$ & $\begin{array}{l}-1.0489 \\
(0.2768)\end{array}$ & \\
\hline HRSTR/10 & $\begin{array}{c}0.0559 \\
(0.0137)\end{array}$ & $\begin{array}{l}0.1086 \\
(0.0326)\end{array}$ & \\
\hline LWALT & $\begin{array}{l}-3.0457 \\
(2.8428)\end{array}$ & $\begin{array}{l}-5.5304 \\
(4.9154)\end{array}$ & \\
\hline MET & $\begin{array}{c}0.1070 \\
(0.1258)\end{array}$ & $\begin{array}{l}0.1543 \\
(0.2178)\end{array}$ & \\
\hline $\mathrm{MCM}$ & $\begin{array}{c}0.1295 \\
(0.1205)\end{array}$ & $\begin{array}{l}0.2412 \\
(0.2095)\end{array}$ & \\
\hline MIN & $\begin{array}{c}0.0984 \\
(0.1337)\end{array}$ & $\begin{array}{l}0.1602 \\
(0.2301)\end{array}$ & $\ldots$ \\
\hline ELE & $\begin{array}{l}-0.0950 \\
(0.1456)\end{array}$ & $\begin{array}{l}-0.2410 \\
(0.2538)\end{array}$ & \\
\hline TRA & $\begin{array}{l}-0.3186 \\
(0.2052)\end{array}$ & $\begin{array}{l}-0.5952 \\
(0.3606)\end{array}$ & \\
\hline INTERC & $\begin{array}{l}29.1457 \\
(27.782)\end{array}$ & $\begin{array}{l}52.9203 \\
(48.049)\end{array}$ & \\
\hline $\begin{array}{l}\log -L \\
-2 \ln \lambda \\
\text { RHS (d) } \\
\text { N. obs. }\end{array}$ & $\begin{array}{c}-1329.0 \\
1186.6 \\
15 \\
2816\end{array}$ & $\begin{array}{c}-1318.0 \\
1208.4 \\
15 \\
2816\end{array}$ & \\
\hline
\end{tabular}

note: asymptotic standard errors in parentheses 
Table 3 - Estimated Coefficients for Wage Equations in Different Bargaining Regimes (single union membership variable included)

\begin{tabular}{|c|c|c|c|c|c|c|}
\hline \multirow[t]{2}{*}{ Variables } & \multicolumn{2}{|c|}{ OLS methods } & \multicolumn{2}{|c|}{ IMR methods } & \multicolumn{2}{|c|}{ IV methods } \\
\hline & $\begin{array}{c}(1) \\
\text { local } \\
\text { bargaining }\end{array}$ & $\begin{array}{c}(2) \\
\text { no local } \\
\text { bargaining }\end{array}$ & $\begin{array}{l}\text { (3) } \\
\quad \text { local } \\
\text { bargaining }\end{array}$ & $\begin{array}{l}(4) \\
\text { no local } \\
\text { bargaining }\end{array}$ & $\begin{array}{c}(5) \\
\text { local } \\
\text { bargaining }\end{array}$ & $\begin{array}{c}(6) \\
\text { no local } \\
\text { bargaining }\end{array}$ \\
\hline & & - & & & & \\
\hline BARGFIT & & & & & $\begin{array}{c}6.6330 \\
(2.8947)\end{array}$ & \\
\hline UDENS & $\begin{array}{c}0.0504 \\
(0.0093)\end{array}$ & $\begin{array}{c}0.0646 \\
(0.0125)\end{array}$ & $\begin{array}{c}0.1360 \\
(0.0396)\end{array}$ & $\begin{array}{c}0.1029 \\
(0.0675)\end{array}$ & $\begin{array}{c}0.0880 \\
(0.0126)\end{array}$ & $\begin{array}{c}0.1132 \\
(0.0233)\end{array}$ \\
\hline MANPC & $\begin{array}{l}-0.1339 \\
(0.0141)\end{array}$ & $\begin{array}{l}-0.0893 \\
(0.0160)\end{array}$ & $\begin{array}{l}-0.1530 \\
(0.0141)\end{array}$ & $\begin{array}{l}-0.0913 \\
(0.0165)\end{array}$ & $\begin{array}{l}-0.1521 \\
(0.0156)\end{array}$ & $\begin{array}{l}-0.0877 \\
(0.0148)\end{array}$ \\
\hline FEMPC & $\begin{array}{l}-0.1036 \\
(0.1521)\end{array}$ & $\begin{array}{l}-0.0870 \\
(0.0181)\end{array}$ & $\begin{array}{c}-0.1016 \\
(0.0147)\end{array}$ & $\begin{array}{l}-0.0830 \\
(0.0188)\end{array}$ & $\begin{array}{l}-0.1019 \\
(0.0164)\end{array}$ & $\begin{array}{l}-0.0834 \\
(0.0169)\end{array}$ \\
\hline LWALT & $\begin{array}{c}0.0743 \\
(0.1749)\end{array}$ & $\begin{array}{c}0.6319 \\
(0.2358)\end{array}$ & $\begin{array}{l}-0.0007 \\
(0.1686)\end{array}$ & $\begin{array}{c}0.7094 \\
(0.2484)\end{array}$ & $\begin{array}{c}0.0288 \\
(0.1873)\end{array}$ & $\begin{array}{c}0.6943 \\
(0.2238)\end{array}$ \\
\hline HRSTR/100 & $\begin{array}{c}0.0072 \\
(0.0047)\end{array}$ & $\begin{array}{c}0.0091 \\
(0.0149)\end{array}$ & $\begin{array}{c}0.0136 \\
(0.0044)\end{array}$ & $\begin{array}{c}0.0174 \\
(0.0512)\end{array}$ & $\begin{array}{c}0.0117 \\
(0.0049)\end{array}$ & $\begin{array}{c}0.0350 \\
(0.0457)\end{array}$ \\
\hline D2 & $\begin{array}{c}0.0184 \\
(0.0058)\end{array}$ & $\begin{array}{c}0.0203 \\
(0.0095)\end{array}$ & $\begin{array}{c}0.0303 \\
(0.0056)\end{array}$ & $\begin{array}{c}0.0219 \\
(0.0128)\end{array}$ & $\begin{array}{c}0.0297 \\
(0.0062)\end{array}$ & $\begin{array}{c}0.0193 \\
(0.0115)\end{array}$ \\
\hline D3 & $\begin{array}{c}0.0432 \\
(0.0051)\end{array}$ & $\begin{array}{l}-0.0035 \\
(0.0136)\end{array}$ & $\begin{array}{c}0.0525 \\
(0.0050)\end{array}$ & - & $\begin{array}{c}0.0512 \\
(0.0056)\end{array}$ & 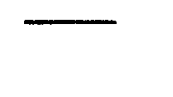 \\
\hline SOUTH & $\begin{array}{l}-0.0369 \\
(0.0111)\end{array}$ & $\begin{array}{l}-0.0682 \\
(0.0162)\end{array}$ & $\begin{array}{l}-0.0317 \\
(0.0103)\end{array}$ & $\begin{array}{l}-0.1037 \\
(0.0202)\end{array}$ & $\begin{array}{l}-0.0345 \\
(0.0114)\end{array}$ & $\begin{array}{l}-0.1057 \\
(0.0171)\end{array}$ \\
\hline MET & $\begin{array}{c}0.0198 \\
(0.0072)\end{array}$ & $\begin{array}{c}0.0063 \\
(0.0110)\end{array}$ & $\begin{array}{c}0.0135 \\
(0.0067)\end{array}$ & $\begin{array}{c}0.0254 \\
(0.0121)\end{array}$ & $\begin{array}{c}0.0131 \\
(0.0755)\end{array}$ & $\begin{array}{c}0.0261 \\
(0.0109)\end{array}$ \\
\hline MCM & $\begin{array}{c}0.0193 \\
(0.0088)\end{array}$ & $\begin{array}{c}0.0072 \\
(0.0126)\end{array}$ & $\begin{array}{c}0.0244 \\
(0.0085)\end{array}$ & $\begin{array}{c}0.0008 \\
(0.0132)\end{array}$ & $\begin{array}{c}0.0232 \\
(0.0094)\end{array}$ & $\begin{array}{c}0.0016 \\
(0.0119)\end{array}$ \\
\hline MIN & $\begin{array}{c}0.0051 \\
(0.0075)\end{array}$ & $\begin{array}{l}-0.0170 \\
(0.0105)\end{array}$ & $\begin{array}{c}0.0028 \\
(0.0073)\end{array}$ & $\begin{array}{l}-0.0131 \\
(0.0109)\end{array}$ & $\begin{array}{c}0.0030 \\
(0.0081)\end{array}$ & $\begin{array}{l}-0.0128 \\
(0.0098)\end{array}$ \\
\hline ELE & $\begin{array}{l}-0.0044 \\
(0.0082)\end{array}$ & $\begin{array}{l}-0.0232 \\
(0.0115)\end{array}$ & $\begin{array}{l}-0.0042 \\
(0.0078)\end{array}$ & $\begin{array}{l}-0.0251 \\
(0.0121)\end{array}$ & $\begin{array}{l}-0.0042 \\
(0.0087)\end{array}$ & $\begin{array}{l}-0.0256 \\
(0.0109)\end{array}$ \\
\hline TRA & $\begin{array}{c}0.0036 \\
(0.0108)\end{array}$ & $\begin{array}{l}-0.0425 \\
(0.0161)\end{array}$ & $\begin{array}{c}0.0023 \\
(0.0101)\end{array}$ & $\begin{array}{l}-0.0503 \\
(0.0179)\end{array}$ & $\begin{array}{c}0.0015 \\
(0.0112)\end{array}$ & $\begin{array}{l}-0.0507 \\
(0.0160)\end{array}$ \\
\hline SELECT & & & $\begin{array}{l}-0.0162 \\
(0.0031)\end{array}$ & $\begin{array}{c}0.0170 \\
(0.0043)\end{array}$ & & \\
\hline INTERC & $\begin{array}{r}9.3237 \\
(1.735)\end{array}$ & $\begin{array}{c}3.7370 \\
(2.3387)\end{array}$ & $\begin{array}{l}10.0297 \\
(1.6727)\end{array}$ & $\begin{array}{c}2.9753 \\
(2.4636)\end{array}$ & $\begin{array}{c}3.1219 \\
(2.2195)\end{array}$ & \\
\hline$R^{2}$ & & & 0189 & 0107 & & \\
\hline $\begin{array}{l}\chi^{2}(d) \\
\log L\end{array}$ & $\begin{array}{l}.100 \\
280.9\end{array}$ & $\begin{array}{l}0.101 \\
128.3\end{array}$ & 342.6 & 134.8 & $\begin{array}{c}623.7 \\
2747.12\end{array}$ & \\
\hline RHS (d) & 13 & 13 & 15 & 14 & 26 & \\
\hline N. obs. & 1612 & 1204 & 1625 & 1191 & 2816 & \\
\hline
\end{tabular}

note: asymptotic standard errors in parentheses 
Table 4-Estimated Coefficients for Wage Equations in Different Bargaining Regimes (union membership dummies included)

\begin{tabular}{|c|c|c|c|c|c|c|}
\hline \multirow[t]{2}{*}{ Variables } & \multicolumn{2}{|c|}{ OLS methods } & \multicolumn{2}{|c|}{ IMR methods } & \multicolumn{2}{|c|}{ IV methods } \\
\hline & $\begin{array}{c}(1) \\
\text { local } \\
\text { bargaining }\end{array}$ & $\begin{array}{c}(2) \\
\text { no local } \\
\text { bargaining }\end{array}$ & $\begin{array}{l}(3) \\
\text { local } \\
\text { bargaining }\end{array}$ & $\begin{array}{c}(4) \\
\text { no local } \\
\text { bargaining }\end{array}$ & $\begin{array}{c}(5) \\
\text { local } \\
\text { bargaining }\end{array}$ & $\begin{array}{c}(6) \\
\text { no local } \\
\text { bargaining }\end{array}$ \\
\hline BARGFIT & & & & & $\begin{array}{c}6.6722 \\
(2.9042)\end{array}$ & \\
\hline UDD1 & $\begin{array}{l}-0.0055 \\
(0.0093)\end{array}$ & $\begin{array}{c}0.0114 \\
(0.0080)\end{array}$ & $\begin{array}{c}0.0363 \\
(0.0217)\end{array}$ & $\begin{array}{c}0.0134 \\
(0.0074)\end{array}$ & $\begin{array}{c}0.0424 \\
(0.0240)\end{array}$ & $\begin{array}{c}0.0170 \\
(0.0066)\end{array}$ \\
\hline UDD2 & $\begin{array}{c}0.0165 \\
(0.0084)\end{array}$ & $\begin{array}{c}0.0266 \\
(0.0080)\end{array}$ & $\begin{array}{c}0.0708 \\
(0.0214)\end{array}$ & $\begin{array}{c}0.0355 \\
(0.0107)\end{array}$ & $\begin{array}{c}0.0781 \\
(0.0237)\end{array}$ & $\begin{array}{c}0.0379 \\
(0.0096)\end{array}$ \\
\hline UDD3 & $\begin{array}{c}0.0323 \\
(0.0095)\end{array}$ & $\begin{array}{c}0.0551 \\
(0.0127)\end{array}$ & $\begin{array}{c}0.0930 \\
(0.0220)\end{array}$ & $\begin{array}{l}-0.0660 \\
(0.1044)\end{array}$ & $\begin{array}{c}0.0962 \\
(0.0244)\end{array}$ & $\begin{array}{c}-0.0543 \\
(0.0941)\end{array}$ \\
\hline MANPC & $\begin{array}{c}-0.1333 \\
(0.0141)\end{array}$ & $\begin{array}{l}-0.0885 \\
(0.0160)\end{array}$ & $\begin{array}{c}-0.1460 \\
(0.0140)\end{array}$ & $\begin{array}{c}-0.0912 \\
(0.0165)\end{array}$ & $\begin{array}{c}-0.1497 \\
(0.0156)\end{array}$ & $\begin{array}{c}-0.0873 \\
(0.0149)\end{array}$ \\
\hline FEMPC & $\begin{array}{c}-0.1031 \\
(0.1524)\end{array}$ & $\begin{array}{c}-0.0873 \\
(0.0181)\end{array}$ & $\begin{array}{l}-0.1030 \\
(0.0148)\end{array}$ & $\begin{array}{l}-0.0830 \\
(0.0188)\end{array}$ & $\begin{array}{c}-0.1018 \\
(0.0164)\end{array}$ & $\begin{array}{c}-0.0838 \\
(0.0170)\end{array}$ \\
\hline LWALT & $\begin{array}{c}0.0761 \\
(0.1755)\end{array}$ & $\begin{array}{c}0.6338 \\
(0.2363)\end{array}$ & $\begin{array}{c}0.0205 \\
(0.1692)\end{array}$ & $\begin{array}{c}0.6992 \\
(0.2489)\end{array}$ & $\begin{array}{c}0.0159 \\
(0.1881)\end{array}$ & $\begin{array}{c}0.6885 \\
(0.2244)\end{array}$ \\
\hline HRSTR/100 & $\begin{array}{c}0.0074 \\
(0.0047)\end{array}$ & $\begin{array}{c}0.0069 \\
(0.0151)\end{array}$ & $\begin{array}{c}0.0106 \\
(0.0044)\end{array}$ & $\begin{array}{c}0.0214 \\
(0.0518)\end{array}$ & $\begin{array}{c}0.0103 \\
(0.0049)\end{array}$ & $\begin{array}{c}0.0321 \\
(0.0467)\end{array}$ \\
\hline D2 & $\begin{array}{c}0.0194 \\
(0.0058)\end{array}$ & $\begin{array}{c}0.0201 \\
(0.0097)\end{array}$ & $\begin{array}{c}0.0285 \\
(0.0056)\end{array}$ & $\begin{array}{c}0.0303 \\
(0.0056)\end{array}$ & $\begin{array}{c}0.0282 \\
(0.0062)\end{array}$ & $\begin{array}{c}0.0162 \\
(0.0115)\end{array}$ \\
\hline D3 & $\begin{array}{c}0.0450 \\
(0.0052)\end{array}$ & $\begin{array}{l}-0.0030 \\
(0.0136)\end{array}$ & $\begin{array}{c}0.0520 \\
(0.0051)\end{array}$ & - & $\begin{array}{c}0.0512 \\
(0.0056)\end{array}$ & ( \\
\hline SOUTH & $\begin{array}{l}-0.0368 \\
(0.0112)\end{array}$ & $\begin{array}{l}-0.0668 \\
(0.0163)\end{array}$ & $\begin{array}{c}-0.0304 \\
(0.0103)\end{array}$ & $\begin{array}{l}-0.0988 \\
(0.0192)\end{array}$ & $\begin{array}{l}-0.0302 \\
(0.0114)\end{array}$ & $\begin{array}{c}-0.0951 \\
(0.0173)\end{array}$ \\
\hline MET & $\begin{array}{c}0.0200 \\
(0.0072)\end{array}$ & $\begin{array}{c}0.0065 \\
(0.0110)\end{array}$ & $\begin{array}{c}0.0136 \\
(0.0068)\end{array}$ & $\begin{array}{c}0.0256 \\
(0.0121)\end{array}$ & $\begin{array}{c}0.0136 \\
(0.0757)\end{array}$ & $\begin{array}{c}0.0262 \\
(0.0109)\end{array}$ \\
\hline $\mathrm{MCM}$ & $\begin{array}{c}0.0190 \\
(0.0088)\end{array}$ & $\begin{array}{c}0.0069 \\
(0.0126)\end{array}$ & $\begin{array}{c}0.0233 \\
(0.0085)\end{array}$ & $\begin{array}{c}0.0014 \\
(0.0132)\end{array}$ & $\begin{array}{c}0.0233 \\
(0.0095)\end{array}$ & $\begin{array}{c}0.0018 \\
(0.0119)\end{array}$ \\
\hline MIN & $\begin{array}{c}0.0047 \\
(0.0075)\end{array}$ & $\begin{array}{l}-0.0174 \\
(0.0105)\end{array}$ & $\begin{array}{c}0.0010 \\
(0.0073)\end{array}$ & $\begin{array}{l}-0.0127 \\
(0.0109)\end{array}$ & $\begin{array}{c}0.0006 \\
(0.0081)\end{array}$ & $\begin{array}{c}-0.0125 \\
(0.0099)\end{array}$ \\
\hline ELE & $\begin{array}{c}-0.0041 \\
(0.0082)\end{array}$ & $\begin{array}{l}-0.0230 \\
(0.0115)\end{array}$ & $\begin{array}{c}-0.0043 \\
(0.0079)\end{array}$ & $\begin{array}{l}-0.0252 \\
(0.0121)\end{array}$ & $\begin{array}{l}-0.0043 \\
(0.0088)\end{array}$ & $\begin{array}{l}-0.0255 \\
(0.0109)\end{array}$ \\
\hline TRA & $\begin{array}{c}0.0039 \\
(0.0108)\end{array}$ & $\begin{array}{l}-0.0428 \\
(0.0161)\end{array}$ & $\begin{array}{c}0.0023 \\
(0.0101)\end{array}$ & $\begin{array}{l}-0.0473 \\
(0.0179)\end{array}$ & $\begin{array}{c}0.0026 \\
(0.0113)\end{array}$ & $\begin{array}{l}-0.0466 \\
(0.0161)\end{array}$ \\
\hline SELECT & & & $\begin{array}{l}-0.0159 \\
(0.0031)\end{array}$ & $\begin{array}{c}0.0176 \\
(0.0043)\end{array}$ & & \\
\hline INTERC & $\begin{array}{r}9.3130 \\
(1.741)\end{array}$ & $\begin{array}{r}3.7175 \\
(2.3438)\end{array}$ & $\begin{array}{c}9.8086 \\
(1.6785)\end{array}$ & $\begin{array}{c}3.0762 \\
(2.4686)\end{array}$ & $\begin{array}{c}3.1791 \\
(2.2255)\end{array}$ & \\
\hline & & $=$ & & & & \\
\hline $\begin{array}{l}\mathrm{R}^{2} \\
\chi^{2}(\mathrm{~d}) \\
\log L\end{array}$ & $\begin{array}{l}0.160 \\
279.8\end{array}$ & $\begin{array}{l}0.100 \\
126.3\end{array}$ & $\begin{array}{l}0.182 \\
329.3\end{array}$ & $\begin{array}{l}0.105 \\
132.0\end{array}$ & $\begin{array}{r}615.7 \\
2743.12\end{array}$ & \\
\hline $\begin{array}{l}\text { RHS (d) } \\
\text { N. obs. }\end{array}$ & $\begin{array}{c}15 \\
1612\end{array}$ & $\begin{array}{c}14 \\
1204\end{array}$ & $\begin{array}{c}16 \\
1625\end{array}$ & $\begin{array}{l}15 \\
1191\end{array}$ & $\begin{array}{c}30 \\
2816\end{array}$ & \\
\hline
\end{tabular}




\section{APPENDIX}

Table A/1 - Description and (weighted) Means of Variables

\section{Variables weighted means (standard errors)}

\begin{tabular}{|c|c|c|c|}
\hline LWAGE & $\log$ of gross yearly wages & $10.30(0.077)$ & $9.77(1.307)$ \\
\hline LWALT & $\log$ of avg. sub-ind. wages & $9.93(0.017)$ & $9.93(0.019)$ \\
\hline UDENS & union density & $0.45(0.190)$ & $0.24(0.275)$ \\
\hline MANPC $^{+}$ & prop. blue-col.workers & 0.65 & 0.69 \\
\hline $\mathrm{FEMPC}^{+}$ & prop. female workers & 0.18 & 0.16 \\
\hline SOUTH $^{+}$ & operating in south & 0.04 & 0.07 \\
\hline $\mathrm{MET}^{+}$ & metal industry & 0.09 & 0.08 \\
\hline $\mathrm{MCM}^{+}$ & machinery ind. & 0.09 & 0.14 \\
\hline $\mathrm{MNN}^{f}$ & mech. precision ind. & 0.13 & 0.11 \\
\hline $\mathrm{ELE}^{+}$ & electr.components ind. & 0.20 & 0.18 \\
\hline $\mathrm{TRA}^{+}$ & transport equip. ind. & 0.23 & 0.20 \\
\hline MECALT ${ }^{+}$ & other mech. ind. & 0.25 & 0.29 \\
\hline $\mathrm{HRSTR}^{+}$ & hours of strike per un-mem. & 16.63 & 5.97 \\
\hline $\mathrm{COVAZ}^{+}$ & $\begin{array}{l}\text { prop. of establ. with formal } \\
\text { bargaining agreement }\end{array}$ & 0.79 & 0.75 \\
\hline $\mathrm{JNEG}^{+}$ & $\begin{array}{l}\text { cooperative union relations } \\
\text { in the establishment }\end{array}$ & 0.61 & 0.16 \\
\hline $\mathrm{D} 1^{+}$ & firm size: $1-50$ employees & 0.07 & 0.55 \\
\hline $\mathrm{D} 2^{+}$ & 51-100 employees & 0.10 & 0.23 \\
\hline $\mathrm{D}^{+}{ }^{+}$ & over 100 employees & 0.83 & 0.21 \\
\hline $\mathrm{UDDO}^{+}$ & union density: UDENS $=0$ & 0.04 & 0.38 \\
\hline $\mathrm{UDD}^{+}$ & $0<$ UDENS $\leq 0.3$ & 0.20 & 0.26 \\
\hline $\mathrm{UDD}_{2}{ }^{+}$ & $0.3<$ UDENS $\leq 0.7$ & 0.66 & 0.26 \\
\hline $\mathrm{UDD}^{+}$ & $0.7<$ UDENS $\leq 1.0$ & 0.10 & 0.10 \\
\hline
\end{tabular}

note: (i) weighted by the number of employees in the establishment

(ii) all variables marked with an $\left({ }^{+}\right)$are binary variables $(0,1)$, and can be interpreted as the relative (weighted) proportion of that category in the sample. 


\section{References}

Addison, J.T. and Portugal, P. (1989), "The Endogeneity of Union Status", Journal of Labor Research, Vol.10, pp.437-41.

Binmore, K., Rubinstein, A. and Wolinsky, A. (1986), "The Nash Bargaining Solution in Economic Modelling", RAND Journal of Economics, Vol. 17, pp.176-88.

Blanchflower, D. (1984), "Union Relative Wage Effects: A Cross-section Analysis Using Establishment Data", British Journal of Industrial Relations, Vol.XXII, pp.311-32.

Blanchflower, D. and Freeman R. (1990), "Going Different Ways: Unionism in the US and Other Advanced OECD Countries", Centre for Economic Performance, LSE, DP.5.

Booth, A. (1985), "The Free Rider Problem and a Social Custom Model of Trade Union Membership ", Quarterly Journal of Economics, Vol.100, pp.253-261.

Corneo, G. (1992), "Social Custom, Management Opposition and the Persistence of Trade Unions", DELTA, WP. 92-19.

Corneo, G. (1993), "Semi-Unionized Bargaining with Endogenous Membership and Management Opposition", Journal of Economics/Zeitschrift für Nationalökonomie, Vol.57, pp.169-88.

Dell'Aringa, C. and Lucifora C. (1992), "Collective Bargaining and Relative Earnings in Italy", DP.23, CRELI, Università Cattolica di Milano.

Dickens, W.T. (1986), "Wages, Employment and the Threat of Collective Action by Workers", National Bureau of Economic Research, WP.1856.

Dickens, W.T. and Katz L.F. (1987a), "Inter-industry Wage Differences and Theories of Wage Determination", National Bureau of Economic Research, WP.2271.

Dickens, W.T. and Katz L.F. (1987b), "Inter-industry Wage Differences and Industry Characteristics", in Lang K. and Leonard J.S. (eds.), Unemployment and the Structure of Labour Markets, New York, Basil Blackwell.

Disney, R, Gosling, A. and Machin S. (1993), "Union Recognition in the UK: a Theoretical and Empirical Analysis", University College London, DP.92-13.

Duncan, G. and Leigh D. (1980), "Wage Determination in the Union and Non-union Sectors: A Sample Selectivity Approach", Industrial and Labor Relation Review, Vol.34, pp.24-34.

Duncan, G. and Leigh D. (1985), "The Endogeneity of Union Status: An Empirical Test", Journal of Labour Economics, Vol.3, pp.385-402.

Flanagan, R., Hartog J. and Theeuwes J. (1992), "Institutions and the Labour Market. Many Questions, Some Answers", paper presented at the EALE Conference: Warwick (UK). 
Freeman, R.B. and Medoff J.L. (1981), "The Impact of the Percentage Organised on Union and Nonunion Wages", The Review of Economics and Statistics, Vol.LXIII, pp.561-72.

Geroski, P.A. and Stewart M.B. (1986), "Specification Induced Uncertainty in the Estimation of Trade Union Wage Differentials from Industry-Level Data", Economica, vol.53, pp.29-39.

Gregg, P. and Naylor R. (1990), "An Inter-establishment Study of Union Recognition in Great Britain, National Institute of Economic Research, mimeo.

Hausman, J.A. (1978), "Specification Tests in Econometrics", Econometrica, Vol.46, 1251-71.

Heckman, J.J. (1979), "Sample Selection Bias as a Specification Error", Econometrica, Vol.47, pp.153-62.

Geroski, P., Hamlin A. P. and Knight, K.G. (1982), "Wages, Strikes and Market Structure", Oxford Economic Papers, Vol.34, pp.276-91.

Layard, R., Nickell, S. and Jackman, R. (1991), Unemployment: Macroeconomic Performance and the Labour Market, Oxford, Oxford University Press.

Lee, L-F., (1978), "Unionism and Wage Rates: A simultaneous Equations Model with Qualitative and Limited Dependent Variables", International Economic Review, Vol.19, pp.415-33.

Lee, L-F. and R.P. Trost (1978), "Estimation of Some Limited Dependent Variable Models with Application to Hausing Demand", Journal of Econometrics, Vol. , pp.35782.

Lewis, H.G. (1983), "Union Relative wage effects: A Survey of Macro Estimates", Journal of Labour Economics, vol.1, pp. 1-27.

Lewis, H.G. (1986), Union Relative Wage Effects: A Survey, University of Chicago Press.

Maddala, G.S. (1983), Limited Dependent and Qualitative Variables in Econometrics, Cambridge, Cambridge University Press.

Moene, K. (1988), "Union's Threats and Wage Determination", Economic Journal, vol.98, pp.471-83.

Naylor, R. and Cripps M. (1993), "An Economic Theory of the Open Shop Trade Union", European Economic Review, forthcoming.

Naylor, R. and Raaum O. (1993), "The Open Shop Union, Wages and Management Opposition", Oxford Economic Papers, forthcoming.

Neumark, D. and Wachter, M.L. (1992), "Union Threat Effects and Nonunion Industry Wage Differentials", National Bureau of Economic Research, WP.4046. 
Robinson, C. and Tomes, N. (1982), "Self-selection and Interprovincial Migration in Canada", Canadian Journal of Economics, Vol.XV, pp.474-502.

Rosen, S. (1969), "Trade Union Power, Threat Effects and the Extent of Organisation", The Review of Economic Studies, Vol.XXXVI, pp.185-96.

Rubinstein, A. (1982), " Perfect Equilibrium in a Bargaining Model ", Econometrica, 50, 97-109.

Stewart, M.B. (1983), "Relative Earnings and Individual Union Membership in the United Kingdom", Economica, Vol.50, pp.111-25.

Stewart, M.B. (1987), "Collective Bargaining Arrangements, Closed Shops and Relative Pay", Economic Journal, Vol.97, pp.140-56.

Willis, R.J. and Rosen, S. (1979), "Education and Self-selection", Journal of Political Economy, Vol.87, pp.S7-S36. 